\title{
Interleukin-18 and IL-18 binding protein
}

\author{
Charles A. Dinarello ${ }^{1,2}$, Daniela Novick ${ }^{3}$, Soohyun Kim ${ }^{4}$ and Gilles Kaplanski ${ }^{5,6}$ \\ 1 Department of Medicine, University of Colorado Denver, Aurora, CO, USA \\ ${ }^{2}$ Department of Medicine, University Medical Center Nijmegen, Nijmegen, Netherlands \\ ${ }^{3}$ Department of Molecular Genetics, Weizmann Institute of Science, Rehovot, Israel \\ ${ }^{4}$ Department of Biomedical Science and Technology, Konkuk University, Seoul, Republic of Korea \\ ${ }^{5}$ UMR-S 1076, Aix Marseille Université, Marseille, France \\ ${ }^{6}$ Service de Médecine Interne, Hôpital de la Conception, Assistance Publique Hôpitaux de Marseille, Marseille, France
}

\section{Edited by:}

Cecilia Garlanda, Istituto Clinico

Humanitas, Italy

Reviewed by:

Kingston H. Mills, Trinity College

Dublin, Ireland

Jean-Philippe Girard, Centre national

de la recherche scientifique, France

*Correspondence:

Charles A. Dinarello, Department of Medicine, University of Colorado

Denver, Denver, CO 80262, USA

e-mail: cdinare333@aol.com
Interleukin-18 (IL-18) is a member of the IL-1 family of cytokines. Similar to IL-1 $\beta$, IL-18 is synthesized as an inactive precursor requiring processing by caspase- 1 into an active cytokine but unlike IL-1 $\beta$, the IL-18 precursor is constitutively present in nearly all cells in healthy humans and animals. The activity of IL-18 is balanced by the presence of a high affinity, naturally occurring IL-18 binding protein (IL-18BP). In humans, increased disease severity can be associated with an imbalance of IL-18 to IL-18BP such that the levels of free IL-18 are elevated in the circulation. Increasing number of studies have expanded the role of IL-18 in mediating inflammation in animal models of disease using the IL-18BP, IL-18-deficient mice, neutralization of IL-18, or deficiency in the IL-18 receptor alpha chain. A role for IL-18 has been implicated in several autoimmune diseases, myocardial function, emphysema, metabolic syndromes, psoriasis, inflammatory bowel disease, hemophagocytic syndromes, macrophage activation syndrome, sepsis, and acute kidney injury, although in some models of disease, IL-18 is protective. IL-18 plays a major role in the production of interferon- $\gamma$ from T-cells and natural killer cells. The IL-18BP has been used safely in humans and clinical trials of IL-18BP as well as neutralizing anti-IL-18 antibodies are in clinical trials. This review updates the biology of IL-18 as well as its role in human disease.

Keywords: inflammation, autoimmune diseases, inflammasomes, interleukin-1, macrophages

\section{INTRODUCTION TO IL-18}

Interleukin-18 (IL-18) was first described in 1989 as "IFN $\gamma$ inducing factor" isolated in the serum of mice following an intraperitoneal injection of endotoxin. Days before, the mice had been pretreated with Propionibacterium acnes, which stimulates the reticuloendothelial system, particularly the Kupffer cells of the liver. Many investigators concluded that the serum factor was IL12. With purification from mouse livers and molecular cloning of "IFN $\gamma$-inducing factor" in 1995 (1), the name was changed to IL-18. Surprisingly, the new cytokine was related to IL-1 and particularly to IL-1 $\beta$. Similar to IL-1 $\beta$, IL-18 is first synthesized as an inactive precursor and without a signal peptide, remains as an intracellular cytokine. The tertiary structure of the IL-18 precursor is closely related to the IL-37 precursor and the intron-exon borders of the IL-18 and IL-37 genes suggest a close association. Since 1995, many studies have used neutralization of endogenous IL-18 or IL-18-deficient mice to demonstrate the role for this cytokine in promoting inflammation and immune responses [reviewed in Ref. (2-4)]. However, the biology of IL-18 is hardly the recapitulation of IL-1 $\beta$. There are several unique and specific differences between IL-18 and IL-1 $\beta$. For example, in healthy human subjects and also in healthy mice, gene expression for IL- $1 \beta$ in blood mononuclear cells and hematopoietic cells is absent and there is no evidence that the IL- $1 \beta$ precursor is constitutively present in epithelial cells (5). In contrast, the IL-18 precursor is present in blood monocytes from healthy subjects and in the epithelial cells of the entire gastrointestinal tract. Peritoneal macrophages and mouse spleen also contain the IL-18 precursor in the absence of disease (5). The IL-18 precursor is also present in keratinocytes and nearly all epithelial cells. In this regard, IL-18 is similar to IL- $1 \alpha$ and IL-33.

\section{PRODUCTION AND ACTIVITY OF IL-18 PROCESSING OF THE IL-18 PRECURSOR BY CASPASE-1}

The IL-18 precursor has a molecular weight of 24,000 and is processed by the intracellular cysteine protease caspase-1, which cleaves the precursor into an active mature molecule of 17,200. As with the processing of IL- $1 \beta$, inactive pro-caspase- 1 is first activated into active caspase- 1 by the nucleotide-binding domain and leucine-rich repeat pyrin containing protein-3 (NLRP3) inflammasome. Following cleavage by active caspase- 1 , mature IL-18 is secreted from the monocyte/macrophage, although over $80 \%$ of the IL-18 precursor remains unprocessed inside the cell. Compared to wild-type mice, mice deficient in caspase- 1 do not release circulating IFN $\gamma$ following endotoxin. IL-12-induced IFN $\gamma$ is also absent in caspase-1-deficient mice (6). Importantly, any phenotypic characteristic of caspase-1-deficient mice must be studied as whether the deficiency is due to reduced IL-1 $\beta$ or IL-18 activity. For example, the caspase-1-deficient mouse is resistant to colitis (7) but the IL-1 $\beta$-deficient mouse is susceptible in the same disease model (8). Since neutralizing antibodies to IL-18 are protective in the dextran sodium sulfate (DSS) colitis model, caspase-1 
deficiency appears to prevent processing of IL-18 $(7,9)$. On the other hand, there are examples where caspase- 1 processing of IL18 is not required. For example, Fas ligand (FasL) stimulation results in release of biologically active IL-18 in caspase-1-deficient murine macrophages (10).

Similar to IL- $1 \alpha$ and IL-33, the IL-18 precursor is constitutively expressed in endothelial cells, keratinocytes, and intestinal epithelial cells throughout the gastrointestinal tract. Macrophages and dendritic cells are the primary sources for the release of active IL-18, whereas the inactive precursor remains in the intracellular compartment of mesenchymal cells. Also, similar to IL- $1 \alpha$ and IL-33, the IL-18 precursor is released from dying cells and processed extracellularly, most likely by neutrophil proteases such as proteinase-3 (11).

Although Fas signaling triggers apoptosis, Fas signaling induces inflammatory cytokine production, including IL-18. In addition to inducing IL-18, Fas signaling activates caspase-8 in macrophages and dendritic cells, which results in processing and release of mature IL-1 $\beta$ and IL-18 (12). It was also reported that the processing of IL-1 $\beta$ and IL-18 takes place independently of NLRP3 or RIP3 (12).

\section{PROCESSING AND SECRETION OF THE IL-18 PRECURSOR BY ADAM 33-MEDIATED VEGF-DEPENDENT MECHANISM}

Because IL-18 stimulates vascular endothelial cells and promotes metastatic tumor cell invasion, studies had examined the mechanisms of IL-18 secretion from gastric cancer cell line. Vascular endothelial cell growth factor-D (VEGF-D) increased the expression as well as the secretion of IL-18 from the gastric cancer cell line (13). Since VEGF-D has a metalloprotease domain, knockdown of ADAM33 was examined and prevented the secretion of IL-18. Moreover, cell proliferation was reduced using ADAM33 small interfering RNA transfectants (13).

\section{SIGNAL TRANSDUCTION BY IL-18}

As shown in Figure 1, IL-18 forms a signaling complex by binding to the IL-18 alpha chain (IL-18R $\alpha$ ), which is the ligand binding chain for mature IL-18; however, this binding is of low affinity. In cells that express the co-receptor, termed IL-18 receptor beta chain (IL-18R $\beta$ ), a high affinity complex is formed, which then signals. The complex of IL- 18 with the IL- $18 \mathrm{R} \alpha$ and IL-18R $\beta$ chains is similar to that formed by other members of the IL-1 family with the co-receptor, the IL-1R accessory chain IL-1RAcP. Following the formation of the heterodimer, the Toll-IL-1 receptor (TIR) domains approximate and it appears that the cascade of sequential recruitment of MyD88, the four IRAKs and TRAF- 6 followed by the degradation of I $\mathrm{B}$ and release of $\mathrm{NF} \kappa \mathrm{B}$ are nearly identical as that for IL-1 (14). However, there are differences between IL-1 and IL-18 signaling. With few exceptions, IL- $1 \alpha$ or IL- $1 \beta$ are active on cells in the low nanograms per milliliter range and often in the picograms per milliliter range. In contrast, IL-18 activation of cells expressing the two IL-18 receptor chains requires $10-20 \mathrm{ng} / \mathrm{mL}$ and sometime higher levels $(15,16)$.

Although nearly all cells express the IL-1RI, not all cells express IL-1RAcP. Similarly, most cells express the IL-18R $\alpha$ but not all cell express the IL-18R $\beta$. IL-18R $\beta$ is expressed on T-cells and dendritic cells but not commonly expressed in mesenchymal cells.

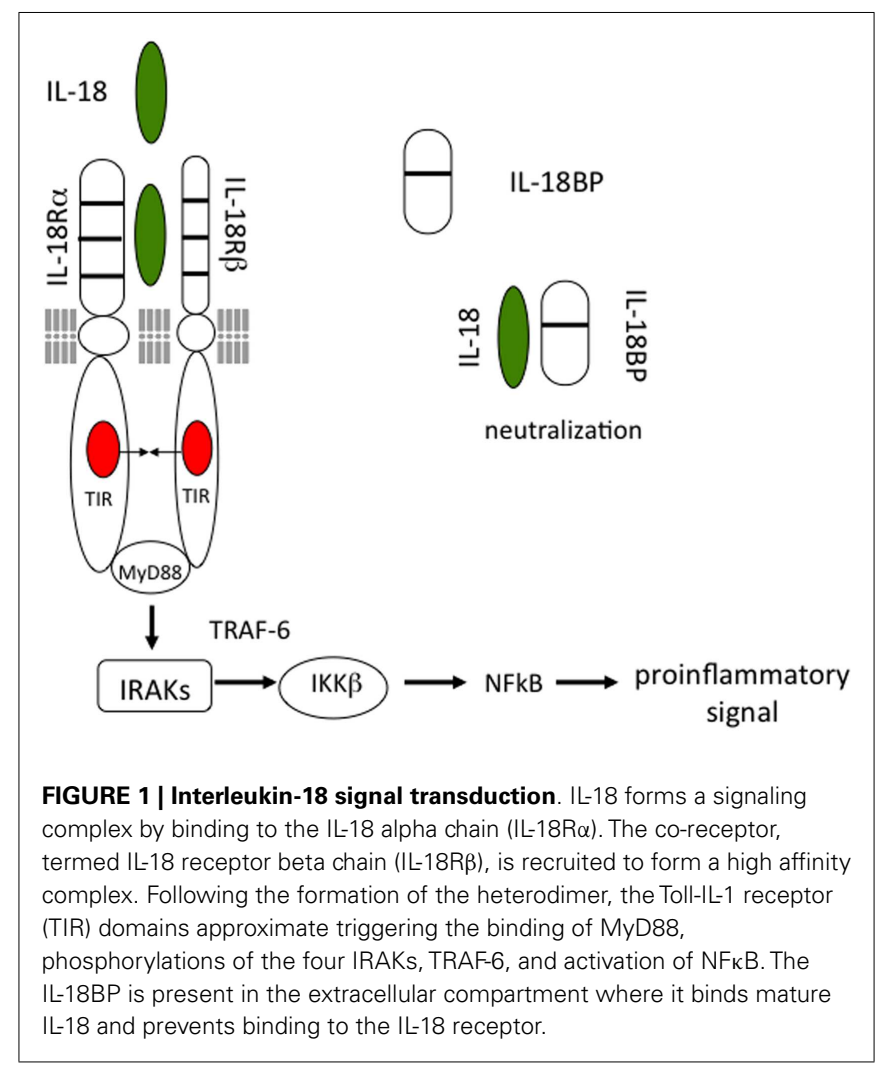

The human lung epithelial cells line A549, derived from a lung carcinoma epithelial cell, does not express IL-18R $\beta$ (17) and there is no signal unless IL-12 is present to induce IL-18R $\beta$ (18). In the absence of IL-18R $\beta$, IL-18 binds to IL- $18 \mathrm{R} \alpha$ without a proinflammatory signal. In A549 cells transfected with IL-18R $\beta$, IL-18 induces IL- 8 and a large number of genes. One of these genes is the former IL-2-induced gene termed NK4 (19) now termed IL-32 (17). IL-32 is not a member of the IL-1 family but plays an important role in the regulation of cytokines such as IL- $1 \beta$ and TNF $\alpha$. Importantly, IL-32 is an IL-18-inducible gene.

\section{IL-18 AS AN IMMUNOREGULATORY CYTOKINE}

\section{ROLE OF IL-18 IN THE PRODUCTION OF IFN $\gamma$}

Together with IL-12, IL-18 participates in the Th1 paradigm. This property of IL-18 is due to its ability to induce IFN $\gamma$ either with IL12 or IL-15. Without IL-12 or IL-15, IL-18 does not induce IFN $\gamma$. IL-12 or IL-15 increases the expression of IL-18R $\beta$, which is essential for IL-18 signal transduction. Importantly, without IL-12 or IL-15, IL-18 plays a role in Th2 diseases (20). The importance of IL18 as an immunoregulatory cytokine is derived from its prominent biological property of inducing IFN $\gamma$ from NK cells. Macrophage colony stimulating factor (M-CSF) induces human blood monocytes to differentiate into a subset of macrophages; these cells express a membrane-bound form of IL-18 (21). Membrane IL18 is expressed in $30-40 \%$ of M-CSF-primed macrophages. In contrast, monocytes, dendritic cells, and monocytes differentiated into M1 macrophages did not express membrane IL-18. Although the expression of membrane IL-18 is caspase-1 dependent (21), LPS treatment was necessary for the release of membrane IL-18 
(21). A major immunoregulating role for IL-18 is on the NK cell. Upon shedding of membrane IL-18 into a soluble form, NK cells expressed CCR7 and produced high levels of IFN $\gamma$. As expected, IFN $\gamma$ production was prevented by neutralization of IL-18. This mechanism may account for the role of IL-18 as major IFN $\gamma$ inducing factor from NK cells and the role of NK cells in the pathogenesis of autoimmune diseases.

The induction of IFN $\gamma$ by IL-18 has been studied with coinducer IL-12. For example, mice injected with the combination of IL-18 plus IL-12 develop high levels of IFN $\gamma$ and die with hypoglycemia, intestinal inflammation, and inanition (22). In leptindeficient mice, IL-18 plus IL-12 induce acute pancreatitis (23). Several human autoimmune diseases are associated with elevated production of IFN $\gamma$ and IL-18. Diseases such as systemic lupus erythematosus, rheumatoid arthritis, Type-1 diabetes, Crohn's disease, psoriasis, and graft versus host disease are thought to be mediated, in part, by IL- 18 .

\section{IL-18, IL-17, AND GAMMA/DELTA T-CELL ACTIVATION}

The role for IL-17 in the pathogenesis of autoimmune diseases has been studied in animal models but also validated in humans treated with either neutralizing antibodies to IL-17 or the IL-17 receptor. However, blockade of IL-1 often prevents or markedly reduces the production of IL-17 in vitro as well as the development of autoimmunity in animal models (24-27). Indeed, there is increased IL- $1 \beta$ as well as increased IL-17 in children born with mutations in the naturally occurring IL-1Ra resulting in a severe inflammatory disease due to excessive IL-1 $\beta$ activity $(28,29)$. The high production of IL-17 in these children is thought to contribute to the severity of the disease. Is there a role for IL-18 in the production of IL-17?

Attention has focused on a role for IL-18 in Th17 responses primarily because both IL- $1 \beta$ and IL-18 are processed into active cytokines via caspase-1. Using a model for multiple sclerosis termed experimental autoimmune encephalomyelitis (EAE) (26), a role for IL-18 was studied. As expected, using the adjuvant of Mycobacterium tuberculosis plus the myelin-derived immunogen for EAE, bone marrow derived mouse dendritic cells released IL$1 \beta$ and IL-18, which was dependent on caspase-1 (30). The primed dendritic cells induced IL-17 from T-cells, which when transferred to non-immunized mice resulted in the encephalomyelitis. However, the disease did not develop when the dendritic cells were exposed to a caspase- 1 inhibitor (30). Treating the mice with either IL- $1 \beta$ or IL-18 restored the ability of the T-cell transfer to induce the disease. Moreover, treating the recipient mice with the caspase1 inhibitor reduced the disease as well as reduced the production of IL-17 from CD4 positive T-cells as well as from gamma-delta T-cells. Gamma-delta T-cells produce IL-17 when stimulated with IL-18 plus IL-23, as these T-cells express high levels of the IL-18 receptor alpha chain. Thus, similar to caspase- 1 dependent IL- $1 \beta$, IL-18 induces T-cells to produce IL-17 and promote autoimmune responses to specific antigens.

\section{IL-18 AND INFLAMMATION \\ PRO-INFLAMMATORY PROPERTIES OF IL-18}

Interleukin-18 exhibits characteristics of other pro-inflammatory cytokines, such as increases in cell adhesion molecules, nitric oxide synthesis, and chemokine production. Blocking IL-18 activity reduces metastasis in a mouse model of melanoma; this is due to a reduction in IL-18-induced expression of vascular call adhesion molecule-1 (31). A unique property of IL-18 is the induction of FasL, which may account for the hepatic damage that takes place in macrophage activation syndrome (MAS) $(10,32)$. The induction of fever, a well-studied property of IL- $1 \alpha$ and IL- $1 \beta$ as well as acute phase proteins, TNF $\alpha$ and IL-6, is not a significant property of IL-18. Injection of IL-18 into mice or rabbits does not produce fever $(33,34)$. In a clinical study of intravenous IL-18 dosing in patients with cancer, chills, and fevers were not common and were Grade 1 (low fevers). Unlike IL- 1 and TNF $\alpha$, fever in humans is observed in all patients at doses of $10 \mathrm{ng} / \mathrm{kg}$ whereas IL-18 fevers were observed in 3 of 21 patients and only at doses of 100 and $200 \mu \mathrm{g} / \mathrm{kg}$ (35).

Unlike IL-1 and TNF $\alpha$, IL-18 does not induce cyclooxygenase-2 and hence there is no production of prostaglandin E2 $(16,36)$. IL18 has been administered to humans for the treatment of cancer in order to increase the activity and expansion of cytotoxic T-cells. Not unexpectedly and similar to several cytokines, the therapeutic focus on IL-18 has shifted from its use as an immune stimulant to inhibition of its activity $(3,37)$.

Because IL-18 can increase IFN $\gamma$ production, blocking IL-18 activity in autoimmune diseases is an attractive therapeutic target since anti-IL-12/23 reduces the severity of Crohn's disease as well as psoriasis. As discussed below, there appears to be a role for blocking IL-18 in Crohn's disease. However, there are several activities of IL-18 that are independent of IFN $\gamma$. For example, IL-18 inhibits proteoglycan synthesis in chondrocytes (38) and proteoglycan synthesis is essential for maintaining healthy cartilage. IL-18 also increases vascular cell adhesion molecule-1 (VCAM-1) expression in endothelial cells independently of IFN $\gamma$. VCAM-1 plays a major role in multiple sclerosis, other autoimmune diseases as well as in the metastatic process (39).

\section{ROLE OF IL-18 IN MODELS OF INFLAMMATORY BOWEL DISEASE}

Inflammatory bowel disease such as Crohn's disease is a complex autoimmune disease. Treatment is initially based on immunosuppressive drugs. Not surprisingly, anti-cytokines such as neutralizing monoclonal antibodies to TNF $\alpha$ (40) or to IL-12/23 provide effective treatment for many patients $(41,42)$. The reduction of IFN $\gamma$ in Crohn's disease is linked to the clinical response to these agents (42). IL-18 is found in affected intestinal lesions from Crohn's disease patients as a mature protein but the IL-18 precursor form is present in uninvolved intestinal tissues (43). This observation was confirmed in a similar assessment of mucosal biopsies from Crohn's disease patients (44). Antisense RNA to IL18 decreased IFN $\gamma$ production in lamina propria mononuclear cells (44).

A commonly used mouse model for colitis is DSS, which is added to the drinking water and which damages the intestinal wall. Thus in DSS-induced colitis, the epithelial barrier defenses against luminal bacterial products are breeched. In this model, reducing IL-18 with a neutralizing antibody is protective and linked to a reduction in IFN $\gamma$ (9). Blocking IL-18 with the IL18 binding protein (IL-18BP) (see Figure 1) also reduces colitis induced by antigen sensitization (45). Since generation of active 
IL-18 requires caspase- 1 , studies have also been performed in mice deficient in caspase- 1 and subjected to DSS colitis. Nevertheless, despite many studies, the role of caspase-1 in DSS colitis remains unclear. The first study showed that mice deficient in caspase-1 were protected $(7,46)$. In addition, treatment of mice with a specific caspase- 1 inhibitor was also effective in protecting against the colitis (47-49). In both studies, the effect of caspase-1 deficiency was linked to reduced IL-18 activity, whereas reducing IL-1 activity with the IL-1Ra was ineffective (7). In support of the role of IL-18 in DSS colitis, inhibition of endogenous merprin $\beta$ to reduce the generation of active IL-18 was protective in DSS colitis (50).

However, a conundrum has developed whether caspase-1 deficiency is protective or detrimental in DSS colitis. DSS colitis is not the optimal model for Crohn's disease as the model is one of rapid loss of the protective barrier of the intestinal epithelium exposing the lamina propria mononuclear cells to a large amount and variety of bacterial products. Using the same DSS model, mice deficient in the adapter protein inflammasome component ASC experienced increased disease, morbidity, and precancerous lesions compared to wild-type mice exposed to DSS (51). Similarly, mice deficient in caspase- 1 died rapidly from DSS compared to wild-type mice (52) whereas mice deficient in caspase-12, in which caspase-1 is enhanced were protected (52). Administration of exogenous IL-18 restored mucosal healing in caspase-1deficient mice (52). Also, mice deficient in NLRP3 were more susceptible to either DSS or TNBS-induced colitis and exhibited decreased IL-1 $\beta$ as well as decreased beta-defensins (53). Macrophages from NLRP3-deficient mice failed to respond to MDP (53). Mice deficient in NLRP6 are also more vulnerable to DSS $(54,55)$ and the susceptibility appears to be due to lack of sufficient IL-18.

How to reconcile these data in mouse models of colitis was addressed by Siegmund (56). It is likely that IL-18, being constitutive in the intestinal epithelium, has a protective role in that the cytokine contributes to maintaining the intestinal barrier. With loss of the barrier, the microbial products stimulate macrophages in the lamina propria and caspase-1 dependent processing of IL-18 results in inflammation. In this model, inhibition of IL-18 production in caspase-1-deficient mice or treatment of wild-type mice with anti-IL-18 antibodies or caspase-1 inhibitors is protective. Worsening of disease in mice deficient in caspase-1 or NLRP3 or NLRP6 may lower the levels of active endogenous IL-18 needed to protect the epithelial barrier. Similarly, active endogenous IL$1 \beta$ may be needed to protect to maintain the epithelial barrier by inducing growth factors.

Although it remains unclear why caspase-1 deficiency worsens DSS colitis, in humans with Crohn's disease, natalizumab, the antibody that blocks the very late antigen-4 (VLA-4), is highly effective in treating the disease. VLA- 4 is the $\alpha 4$ subunit of the $\beta-1$ integrin. Anti-VLA- 4 binds to the surface of macrophages and other myeloid cells and prevents the binding of these cells to the VLA-4 receptor on endothelial cells known as VCAM-1. Thus, the antibody disables the function of VCAM-1 and prevents the passage of macrophages and other myeloid cells into tissues such as the intestine in Crohn's disease and the brain in multiple sclerosis. Since IL-18 induces VCAM-1, blocking IL-18 would also reduce the passage of cells through the endothelium into to intestine.

\section{IL-18, HYPERPHAGIA, AND THE METABOLIC SYNDROME}

Whereas there is no constitutive gene expression for IL- $1 \beta$ in freshly obtained human PBMC, the same cells express constitutive mRNA for IL-18 (5). In western blot analysis from the same cells, the IL-18 precursor was present but not the IL- $1 \beta$ precursor. Similar observations were also made in mice (5). These findings suggest that IL-18 may act as regulator of homeostasis. Starting at age 16 weeks of age, IL-18-deficient mice start to overeat, become obese, and exhibit lipid abnormalities; there is increased atherosclerosis, insulin resistance, and diabetes mellitus reminiscent of the metabolic syndrome (57). IL-18R $\alpha$ deficient mice also develop a similar phenotype. The higher body weight is attributed to enhanced food intake, in which the IL-18-deficient mice begin to diverge from wild-type animals at a relatively early age, and to reach values $30-40 \%$ higher than that of wild-type mice. Others have observed similar findings (58). A striking finding was an increase of more than $100 \%$ in the percent of adipose tissue in the IL-18-deficient animals that was accompanied by fat deposition in the arterial walls. The insulin resistance in these mice is corrected by exogenous recombinant IL-18. Mice deficient in IL-18 respond normally to a challenge with exogenous leptin suggesting that expression of the leptin receptor is unaffected. The unexpected and unique mechanism is responsible for the higher food intake in the IL-18-deficient animals appears to be due a central nervous system loss of appetite control. IL-18-deficient mice eat throughout the day whereas wild-type mice eat once, nocturnally.

\section{IL-18 IN HEART DISEASE}

Heart disease includes coronary vessel disease with associated myocardial infarction, post viral myocardiopathies, autoimmune heat disease, and chronic heart failure. Although survival from an acute myocardial infarction has decreased dramatically due to improved acute care, patients often progress to heart failure due to post infarction remodeling of the ventricles. Treatment options for heart failure vary but reducing cytokines is now being tested as a possible therapy. Based on pre-clinical as well as pilot clinical trials, blocking TNF $\alpha$ was tested in large trials but failed; using a higher dose of an antibody to TNF $\alpha$ (infliximab), there were more deaths compared to the placebo-treated patients. There are also preclinical studies demonstrating that blockade of IL- $1 \beta$ is effective $(59,60)$ and clinical trials using anakinra have revealed that blockade of IL-1 is effective in reducing post infarction remodeling (61, 62 ) as well as increased exercise tolerance (63). In fact, the largest trial in 17,200 patients using a neutralizing antibody to IL- $1 \beta$ aims to reduce cardiovascular events in high risk patients (64).

Increasing numbers of animal and clinical studies indicate a role for IL-18 in heart disease. The myocardium of patients with ischemic heart failure express the alpha chain of the IL- 18 receptor and have elevated levels of circulating IL-18 and associated with death (65). Daily administration of IL-18 results in ventricular hypertrophy, increased collagen (66), and elevated left ventricular diastolic pressure in mice (67). As with all cytokine studies, validation of the role of a cytokine in a disease process is best assessed by specific blockade. In a model of myocardial suppression associated 
with septic shock, mice were injected with LPS and a neutralizing antibody to murine IL-18 was administered (68). The rationale for the experiment was that IL-18 mediates the production of TNF $\alpha$ and IL- $1 \beta$ and to induce the expression of intercellular adhesion molecule-1 (ICAM-1) and VCAM-1. Mice were injected with LPS and left ventricular developed pressure was determined. Left ventricular developed pressure was depressed by 38\% $6 \mathrm{~h}$ after LPS but pretreatment with anti-mouse IL-18 antibody attenuated LPSinduced myocardial dysfunction (by 92\%) and ICAM-1/VCAM-1 expression (50 and 35\% reduction, respectively).

In another study, human atrial muscle strips were obtained from patients undergoing by-pass surgery and the tissue was exposed to ischemia while contractile strength was measured. The addition of IL-18BP to the perfusate during and after the ischemic event resulted in improved contractile function from $35 \%$ of control to $76 \%$ with IL-18BP (69). IL-18BP treatment also preserved intracellular tissue creatine kinase levels (by 420\%). Steady-state mRNA levels for IL-18 were elevated after ischemic and the concentration of IL-18 in myocardial homogenates was increased (control, $5.8 \mathrm{pg} / \mathrm{mg}$ versus I/R, $26 \mathrm{pg} / \mathrm{mg}$ ). Active IL-18 requires cleavage of its precursor form by caspase-1; inhibition of caspase- 1 also attenuated the depression in contractile force after ischemia (from $35 \%$ of control to $75.8 \%$ in treated atrial muscle). Because caspase- 1 also cleaves the IL- $1 \beta$ precursor, IL- 1 receptor blockade was accomplished by using the IL-1 receptor antagonist. IL-1 receptor antagonist added to the perfusate also resulted in a reduction of ischemia-induced contractile dysfunction.

In summary, these studies demonstrate a role for IL-18 in heart disease. Moreover, endogenous IL-18 is induced by IL- $1 \beta$ via caspase-1 under ischemic conditions in human myocardial tissue and that inhibition of caspase- 1 reduces the processing of endogenous precursors of IL-18 and IL- $1 \beta$ and thereby prevents ischemia-induced myocardial dysfunction.

\section{IL-18 AS A PROTECTIVE CYTOKINE}

As stated above, mice deficient in caspase- 1 experience increased disease severity when subjected to DSS colitis and that administration of exogenous IL-18 restored mucosal healing in these mice (52). In addition, IL-18 deficiency or IL-18 receptor deficiency results in the development of a metabolic syndrome in mice. Mice deficient in NLRP3 are more susceptible to DSS colitis, which is thought to be due to decreased IL-18 (53). Mice deficient in NLRP6 are also more vulnerable to DSS $(54,55)$ and the susceptibility appears to be due to lack of sufficient IL-18. As discussed below, a protective role for IL-18 is not limited to the gastrointestinal track. In the eye, a condition resembling "wet macula degeneration" worsens with antibodies to IL-18 (70).

Thus, there are a growing number of studies, which support a protective role for IL-18. The fact that mice deficient in IL-18 develop a metabolic syndrome-like phenotype is consistent with a role for IL-18 in homeostasis. A study in age related macular degeneration is also consistent with a protective role for IL-18. In that study, drusen, which is mixture of complement-derived and apolipoproteins and lipids, were shown to activate NLRP3 and induce the production of mature IL-1 $\beta$ and IL-18 (70). In a mouse model of "wet" age related macular degeneration, the disease was worse in mice deficient in NLRP3 but not in IL-1RI deficient mice (70). Therefore, IL-18 rather than IL- $1 \alpha$ or IL-1 $\beta$ were protective and upon administration of IL-IL-18, the disease severity improved. Taken together, there is a case for IL- 18 being a protective rather than inflammatory cytokine.

\section{IL-18 BINDING PROTEIN}

\section{THE DISCOVERY OF THE IL-18BP}

The discovery of the IL-18BP took place during the search for the soluble receptors for IL-18 (71). IL-18BP is a constitutively secreted protein, with an exceptionally high affinity for IL-18 (400 pM) (72)

(Figure 1). Present in the serum of healthy humans at a 20 -fold molar excess compared to IL-18 (73), IL-18BP may contribute to a default mechanism by which a Th1 response to foreign organisms is blunted in order to reduce triggering an autoimmune responses to a routine infection. IL-18BP deviates from the classical definition of soluble receptors since it does not correspond to the extracellular ligand binding domain of the IL-18 receptor, but is rather encoded by a separate gene. Thus IL-18BP belongs to a separate family of secreted proteins. As shown in Figure 1, IL-18BP contains only one IgG domain whereas the Type II IL-1 receptor contains three domains. In this regard, the single IgG domain of IL-18BP is similar to SIGIRR, which also has a single IgG domain and also functions as a decoy receptor. The salient property of IL$18 \mathrm{BP}$ in immune responses is in down-regulating Th1 responses by binding to IL-18 and thus reducing the induction of IFN $\gamma(20)$. Since IL-18 also affects Th2 responses, IL-18BP also has properties controlling a Th2 cytokine response (20).

\section{BALANCE OF IL-18 AND IL-18BP IN HUMAN DISEASE}

IL-18 binding protein has a classic signal peptide, and therefore is readily secreted. Serum levels in healthy subjects are in the range of $2,000-3,000 \mathrm{pg} / \mathrm{mL}$ compared to the levels of IL- 18 in the same sera of $80-120 \mathrm{pg} / \mathrm{mL}$ (73). Moreover, IL-18BP binds IL-18 with an affinity of $400 \mathrm{pM}$, an affinity significantly higher than that of IL-18R $\alpha$. Because a single IL-18BP molecule binds a single IL-18 molecule, one can calculate bound versus free IL-18 in a mixture of both molecules (73).

If one examines immunologically mediated diseases where IFN $\gamma$ plays a pathological role such as Wegener's granulomatosis and systemic lupus erythematosus, one must consider the level of free IL-18 compared to IL-18 bound to IL-18BP. In fact, in these diseases both IL-18BP and IL-18 are high $(74,75)$ but the level of IL-18BP is not sufficiently high enough to neutralize IL18 and therefore, the level of free IL-18 is higher than in healthy subjects. In MAS where IFN $\gamma$ plays a pathological role, both IL18BP and IL-18 are also high but the clinical and hematological abnormalities correlate with elevated free IL-18 (32).

A unique property of IL-18BP is that the molecule also binds IL37 (76) and in doing so, enhances the ability of IL-18BP to inhibit the induction of IFN $\gamma$ by IL-18. IL-37 binds to the IL-18R $\alpha$ with a very low affinity but in mice expressing human IL-37, a profound anti-inflammatory effect is observed (77), particularly of LPS-induced cytokines and dendritic cell maturation (77). Human IL-37-expressing mice are also resistant to colitis (78). Thus, the anti-inflammatory property of IL-37 can be affected by the concentration of IL-18BP. As the concentration of IL-18BP increases and binds IL-37, there is the possibility that IL-37 becomes less 
available as an anti-inflammatory cytokine. Indeed this has been observed in mice injected with IL-18BP. At low dosing of IL-18BP, there is reduced inflammation in a model of rheumatoid arthritis but as the doing of IL-18BP increases, the anti-inflammatory properties of IL-18BP are lost (79). Table 1 summarizes several disease states in which IL-18 as well as IL-18BP are measured and in some studies, the level of free IL-18 has been reported.

\section{REGULATION OF IL-18BP}

IL-18 binding protein is highly regulated at the level of gene expression and unexpectedly, IFN $\gamma$ increases gene expression and synthesis of IL-18BP $(80,81)$. Therefore, IFN $\gamma$ driving an increase in the natural and potent inhibitor of IL-18 falls into the category of a negative feed-back loop. The concept is supported by clinical data showing that patients being treated with IFN $\alpha$ for hepatitis have elevated levels of IL-18BP $(82,83)$. IL-27, like IFN $\gamma$, functions as both a pro- as well as an anti-inflammatory cytokine and both may accomplish their roles as anti-inflammatory cytokines at the level of increased production of IL-18BP. In the skin, IL-27 also acts through a negative feed-back loop for inflammation. IL-27 is acting, as is IFN $\gamma$, by induction of IL-18BP gene expression and synthesis (84).

\section{VIRAL IL-18BP}

Natural neutralization of human IL-18 by IL-18BP takes place during a common viral infection. In Molluscum contagiosum infection, characterized by raised but bland eruptions, there are large numbers of viral particles in the epithelial cells of the skin but histologically there are few inflammatory or immunologically active cells in or near the lesions. Clearly, the virus fails to elicit an inflammatory or immunological response. Amino acid similarity exists between human IL-18BP and a gene found in various members of the poxviruses; the greatest degree of homology is found to be expressed by $M$. contagiosum gene (85). The ability of viral IL-18BP to reduce the activity of mammalian IL-18 likely explains the lack of inflammatory and immune cells in the virally infected tissues and provides further evidence for the natural ability of IL-18BP to interfere with IL-18 activity.

\section{HEMOPHAGOCYTIC LYMPHO HISTIOCYTOSIS AND MACROPHAGE ACTIVATION SYNDROME}

Hemophagocytic lympho histiocytosis (HLH) syndrome is a rare life-threatening condition characterized by a severe hyperinflammatory state. There is a genetic form of HLH called familial hemophagocytic lympho histiocytosis (fHLH). However, HLH can

Table 1 | Levels of IL-18 and IL-18BP in human disease.

\begin{tabular}{|c|c|c|c|c|}
\hline Disease & IL-18a & IL-18BPb & Free IL-18 ${ }^{a}$ & Reference \\
\hline Sepsis & $500-2,000$ & ND & ND & Emmanuilidis et al. (100) \\
\hline Sepsis & $250-10,000$ & 22.5 & $250-3,000$ & Novick et al. (73) \\
\hline Trauma & $300-600$ & ND & ND & Mommsen et al. (101) \\
\hline Schizophrenia & 518 & 10 & 253 & Palladino et al. (102) \\
\hline Ulcerative colitis & 274 & ND & ND & Haas et al. (103) \\
\hline Ulcerative colitis & 393 & 4.7 & 250 & Ludwiczek et al. (104) \\
\hline Crohn's disease & 387 & ND & ND & Haas et al. (103) \\
\hline Crohn's disease & 546 & 5 & 340 & Ludwiczek et al. (104) \\
\hline Wegener's disease & 240 & 14.5 & 84 & Novick et al. (74) \\
\hline Rheumatoid arthritis & $230-400$ & ND & ND & Bokarewa and Hultgren (105) \\
\hline SLE $^{\mathrm{C}}$ & 700 & 7.5 & 408 & Favilli et al. (99) \\
\hline SLE $^{\mathrm{C}}$ & 400 & 15 & 167 & Novick et al. (75) \\
\hline MAS $^{d}$ & 2,200 & 35 & 660 & Mazodier et al. (32) \\
\hline Systemic JIA & $1,600-78,000$ & ND & ND & Jelusic et al. (106) \\
\hline Adult Still's disease & $1,000-6,000$ & ND & ND & Kawashima et al. (107) \\
\hline Myocardial infarction & 238 & ND & ND & Blankenberg et al. (108) \\
\hline Myocardial infarction & 355 & ND & ND & Narins et al. (109) \\
\hline Coronary artery disease & 356 & 13.7 & 125 & Thompson et al. (110) \\
\hline Metabolic syndrome & 380 & ND & ND & Troseid et al. (111) \\
\hline Acute kidney injury ${ }^{f}$ & 500 & ND & ND & Parikh et al. (112) \\
\hline Acute kidney injury ${ }^{f}$ & 2,000 & ND & ND & Vaidya et al. (113) \\
\hline Acute kidney injury ${ }^{f}$ & $>360$ & ND & ND & Parikh et al. (114) \\
\hline Acute kidney injury ${ }^{f}$ & 884 & ND & ND & Sirota et al. (115) \\
\hline
\end{tabular}

a Levels in picograms per milliliter, range, or mean.

${ }^{b}$ Levels in nanograms per milliliter, range, or mean.

'Systemic lupus erythematosus.

${ }^{d}$ Macrophage activation syndrome.

e Systemic juvenile idiopathic arthritis.

${ }^{f}$ Urine levels (mean in picograms per milliliter). 
be secondary to infections and lymphoma, and is called secondary MAS. The development of MAS is associated with several infectious diseases, notably due to Epstein-Barr virus, cytomegalovirus, herpes virus, or intracellular bacteria and parasites and also of various lymphomas, especially of T-cell lineage. In addition, patients with rheumatological conditions, particularly systemic onset juvenile arthritis (sJIA), but also systemic lupus erythematosus, Kawasaki disease, or systemic vasculitis can develop MAS (86-89). One of the most prominent hematologic and metabolic characteristics of MAS is thrombocytopenia and hepatic injury, respectively. Indeed, IFN $\gamma$ may be responsible for the thrombocytopenia as well as several of the immunological abnormalities of the disorder.

\section{IL-18 IN THE HEMOPHAGOCYTIC SYNDROMES}

In the case of fHLH or MAS, gene expression for IL-18 is upregulated in peripheral mononuclear cells $(90,91)$ and serum IL-18 is unusually elevated (32, 92-95). Although levels of IL18 in the circulation are below $1 \mathrm{ng} / \mathrm{mL}$ in inflammatory diseases such as severe sepsis, in active phase of fHLH or EBV-HLH, serum IL-18 is usually in the range of $5-7 \mathrm{ng} / \mathrm{mL}$, and in $\mathrm{fHLH}$ complicating XIAP gene mutations as well as in MAS complicating sJIA, levels of circulating IL- 18 can be in $20-30 \mathrm{ng} / \mathrm{mL}$ range $(32,96-98)$. However, it is necessary to calculate the level of free IL-18 since IL-18BP is present in the circulation in health and disease (73) (see Table 1) in lupus $(75,99)$, Wegener's granulomatosis (74). In patients with MAS, free IL-18 but not IL-12

\section{REFERENCES}

1. Okamura H, Nagata K, Komatsu T, Tanimoto T, Nukata Y, Tanabe $\mathrm{F}$, et al. A novel costimulatory factor for gamma interferon induction found in the livers of mice causes endotoxic shock. Infect Immun (1995) 63:3966-72.

2. Boraschi D, Dinarello CA. IL18 in autoimmunity: review. Eur Cytokine Netw (2006) 17(4):224-52.

3. Dinarello CA. Interleukin-18 and the pathogenesis of inflammatory diseases. Semin Nephrol (2007) 27(1):98-114. doi:10.1016/j. semnephrol.2006.09.013

4. Tsutsui $H, \quad$ Nakanishi K. Immunotherapeutic applications of IL-18. Immunotherapy (2012) 4(12):1883-94. doi:10.2217/imt.12.137

5. Puren AJ, Fantuzzi G, Dinarello CA. Gene expression, synthesis and secretion of IL-1 $\beta$ and IL-18 are differentially regulated in human blood mononuclear cells and mouse spleen cells. Proc Natl Acad Sci U S A (1999) 96:2256-61. doi:10.1073/pnas.96.5.2256

6. Fantuzzi G, Reed DA, Dinarello CA. IL-12-induced IFN $\gamma$ is dependent on caspase- 1 processing of the IL-18 precursor. J Clin Invest
(1999) 104(6):761-7. doi:10.1172/ JCI7501

7. Siegmund B, Lehr HA, Fantuzzi G, Dinarello CA. IL-1beta-converting enzyme (caspase-1) in intestinal inflammation. Proc Natl Acad Sci U S A (2001) 98(23):13249-54. doi:10.1073/pnas.231473998

8. Besedovsky H, del Rey A, Sorkin E, Dinarello CA. Immunoregulatory feedback between interleukin1 and glucocorticoid hormones. Science (1986) 233(4764):652-4. doi:10.1126/science. 3014662

9. Siegmund B, Fantuzzi G, Rieder F, Gamboni-Robertson F, Lehr HA, Hartmann G, et al. Neutralization of interleukin-18 reduces severity in murine colitis and intestinal IFN- $\gamma$ and TNF- $\alpha$ production. Am J Physiol Regul Integr Comp Physiol (2001) 281(4):R1264-73.

10. Tsutsui H, Matsui K, Okamura H, Nakanishi K. Pathophysiological roles of interleukin-18 in inflammatory liver diseases. Immunol Rev (2000) 174:192-209. doi:10.1034/ j.1600-0528.2002.017418.x

11. Sugawara S, Uehara A, Nochi T, Yamaguchi T, Ueda H, Sugiyama A, et al. Neutrophil proteinase 3mediated induction of bioactive IL-18 secretion by human oral epithelial cells. J Immunol (2001) 167(11):6568-75.

concentrations significantly correlated with clinical status and the biologic markers of MAS such as anemia $(p<0.001)$, hypertriglyceridemia, and hyperferritinemia $(p<0.01)$ and also with markers of Th1 lymphocyte or macrophage activation, such as elevated concentrations of IFN $\gamma$ and soluble IL- 2 and TNF $\alpha$ receptor concentrations (32).

\section{CONCLUDING REMARKS}

Although clinical trials of IL-1 blocking therapies have focused attention on the biology IL-1, the role of IL-18 in health and disease is derived from animal models and measurements of IL-18 in various disease conditions. Nevertheless, with clinical trials of IL$18 \mathrm{BP}$ as well as neutralizing antibodies to IL-18 now underway, the role for this cytokine in treating human disease will become apparent. Certainly validated animal models support a role for IL-18 in acute renal injury, psoriasis, heart failure, MAS, and inflammatory bowel disease. Whether suppression of IL-18 will affect IL-17mediated diseases such as multiple sclerosis or reduce metastatic melanoma will also be determined in clinical trials.

\section{ACKNOWLEDGMENTS}

The authors thank Tania Azam, Karin Mazodier, Laura Chiossonne, Catherine Farnarier, and Eric Vivier. These studies are supported by NIH AI-15614, AR-45584, and CA-04 6934 (to Charles A. Dinarello) and Agence Nationale de la Recherche-Maladies Rares 2007 et Projet National de Recherche Clinique 2007 (to Gilles Kaplanski).

12. Bossaller L, Chiang PI, SchmidtLauber C, Ganesan S, Kaiser WJ, Rathinam VA, et al. Cutting edge: FAS (CD95) mediates noncanonical IL-1beta and IL-18 maturation via caspase- 8 in an RIP3independent manner. J Immunol (2012) 189(12):5508-12. doi:10. 4049/jimmunol.1202121

13. Kim KE, Song H, Hahm C, Yoon SY, Park S, Lee HR, et al. Expression of ADAM33 is a novel regulatory mechanism in IL-18secreted process in gastric cancer. J Immunol (2009) 182(6):3548-55. doi:10.4049/jimmunol.0801695

14. Weber A, Wasiliew P, Kracht M. Interleukin-1 (IL-1) pathway. $\mathrm{Sci}$ Signal (2010) 3(105):cml. doi: 10 . $1126 /$ scisignal. $3105 \mathrm{~cm} 1$

15. Morel JC, Park CC, Woods JM, Koch AE. A novel role for interleukin-18 in adhesion molecule induction through NFkappa $\mathrm{B}$ and phosphatidylinositol (PI) 3-kinase-dependent signal transduction pathways. J Biol Chem (2001) 276(40):37069-75. doi:10. 1074/jbc.M103574200

16. Lee JK, Kim SH, Lewis EC, Azam T, Reznikov LL, Dinarello CA. Differences in signaling pathways by IL-1beta and IL-18. Proc Natl Acad Sci U S A (2004) 101(23):8815-20. doi:10.1073/pnas.0402800101
17. Kim SH, Han SY, Azam T, Yoon DY, Dinarello CA. Interleukin32: a cytokine and inducer of TNFalpha. Immunity (2005) 22(1):131-42. doi:10.1016/S10747613(04)00380-2

18. Nakanishi K, Yoshimoto T, Tsutsui $\mathrm{H}$, Okamura $\mathrm{H}$. Interleukin18 regulates both Th1 and Th2 responses. Ann Rev Immunol (2001) 19:423-74. doi:10.1146/ annurev.immunol.19.1.423

19. Dahl CA, Schall RP, He HL, Cairns JS. Identification of a novel gene expressed in activated natural killer cells and T cells. J Immunol (1992) 148(2):597-603.

20. Nakanishi K, Yoshimoto T, Tsutsui $\mathrm{H}$, Okamura $\mathrm{H}$. Interleukin18 is a unique cytokine that stimulates both Th1 and Th2 responses depending on its cytokine milieu. Cytokine Growth Factor Rev (2001) 12(1):53-72. doi:10.1016/S1359-6101(00) 00015-0

21. Bellora F, Castriconi R, Doni A, Cantoni C, Moretta L, Mantovani $\mathrm{A}$, et al. M-CSF induces the expression of a membrane-bound form of IL-18 in a subset of human monocytes differentiating in vitro toward macrophages. Eur J Immunol (2012) 42(6):1618-26. doi:10.1002/eji.201142173 
22. Nakamura S, Otani T, Ijiri Y, Motoda R, Kurimoto M, Orita K. IFN-gamma-dependent and -independent mechanisms in adverse effects caused by concomitant administration of IL-18 and IL-12. J Immunol (2000) 164(6):3330-6.

23. Sennello JA, Fayad R, Pini M, Gove ME, Ponemone V, Cabay RJ, et al. Interleukin-18, together with interleukin-12, induces severe acute pancreatitis in obese but not in nonobese leptin-deficient mice. Proc Natl Acad Sci U S A (2008) 105(23):8085-90. doi: 10 . 1073/pnas.0804091105

24. Coccia M, Harrison OJ, Schiering $\mathrm{C}$, Asquith MJ, Becher B, Powrie F, et al. IL-1beta mediates chronic intestinal inflammation by promoting the accumulation of IL-17A secreting innate lymphoid cells and CD4+ Th17 cells. J Exp Med (2012) 209(9):1595-609. doi: 10.1084/jem.20111453

25. Joosten LA. Excessive interleukin-1 signaling determines the development of Th1 and Th17 responses in chronic inflammation. Arthritis Rheum (2010) 62(2):320-2. doi: 10.1002/art. 27242

26. Sutton C, Brereton C, Keogh B, Mills KH, Lavelle EC. A crucial role for interleukin (IL)1 in the induction of IL-17producing $\mathrm{T}$ cells that mediate autoimmune encephalomyelitis. J Exp Med (2006) 203(7):1685-91. doi:10.1084/jem.20060285

27. Sutton CE, Lalor SJ, Sweeney CM, Brereton CF, Lavelle EC, Mills KH. Interleukin-1 and IL-23 induce innate IL-17 production from gammadelta $\mathrm{T}$ cells, amplifying Th17 responses and autoimmunity. Immunity (2009) 31(2):331-41. doi:10.1016/ j.immuni.2009.08.001

28. Aksentijevich I, Masters SL, Ferguson PJ, Dancey P, Frenkel J, van Royen-Kerkhoff A, et al. An autoinflammatory disease with deficiency of the interleukin-1receptor antagonist. $N$ Engl J Med (2009) 360(23):2426-37. doi:10. 1056/NEJMoa0807865

29. Reddy S, Jia S, Geoffrey R, Lorier R, Suchi M, Broeckel U, et al. An autoinflammatory disease due to homozygous deletion of the IL1RN locus. $N$ Engl $\mathrm{J} \mathrm{Med}$ (2009) 360(23):2438-44. doi:10. 1056/NEJMoa0809568

30. Lalor SJ, Dungan LS, Sutton CE, Basdeo SA, Fletcher JM, Mills KH. Caspase-1-processed cytokines IL-1beta and IL-18 promote IL-17 production by gammadelta and CD4 T cells that mediate autoimmunity. J Immunol (2011) 186(10):5738-48. doi:10. 4049/jimmunol.1003597

31. Vidal-Vanaclocha F, Fantuzzi G, Mendoza L, Fuentes AM, Anasagasti MJ, Martin J, et al. IL-18 regulates IL-1betadependent hepatic melanoma metastasis via vascular cell adhesion molecule-1. Proc Natl Acad Sci U S A (2000) 97(2):734-9. doi:10.1073/pnas.97.2.734

32. Mazodier K, Marin V, Novick D, Farnarier C, Robitail S, Schleinitz $\mathrm{N}$, et al. Severe imbalance of IL-18/IL-18BP in patients with secondary hemophagocytic syndrome. Blood (2005) 106(10):3483-9. doi:10.1182/blood-2005-05-1980

33. Gatti S, Beck J, Fantuzzi G, Bartfai T, Dinarello CA. Effect of interleukin-18 on mouse core body temperature. Am J Physiol Regul Integr Comp Physiol (2002) 282(3):R702-9.

34. Li S, Goorha S, Ballou LR, Blatteis CM. Intracerebroventricular interleukin-6, macrophage inflammatory protein-1 beta and IL-18: pyrogenic and PGE(2)-mediated? Brain Res (2003) 992(1):76-84. doi:10.1016/j.brainres.2003.08. 033

35. Robertson MJ, Mier JW, Logan T, Atkins M, Koon H, Koch KM, et al. Clinical and biological effects of recombinant human interleukin-18 administered by intravenous infusion to patients with advanced cancer. Clin Cancer Res (2006) 12(14 Pt 1):4265-73. doi:10.1158/1078-0432.CCR-060121

36. Reznikov LL, Kim SH, Westcott JY, Frishman J, Fantuzzi G, Novick D, et al. IL-18 binding protein increases spontaneous and IL-1-induced prostaglandin production via inhibition of IFNgamma. Proc Natl Acad Sci U S A (2000) 97(5):2174-9. doi:10.1073/ pnas.040582597

37. Tak PP, Bacchi M, Bertolino M. Pharmacokinetics of IL-18 binding protein in healthy volunteers and subjects with rheumatoid arthritis or plaque psoriasis. Eur J Drug Metab Pharmacokinetics (2006) 31(2):109-16. doi:10.1007/ BF03191127

38. Joosten LA, van De Loo FA, Lubberts E, Helsen MM, Netea MG, van der Meer JW, et al. An IFNgamma-independent proinflammatory role of IL-18 in murine streptococcal cell wall arthritis. $J$ Immunol (2000) 165(11):6553-8.

39. Carrascal MT, Mendoza L, Valcarcel M, Salado C, Egilegor E, Telleria $\mathrm{N}$, et al. Interleukin-18 binding protein reduces b16 melanoma hepatic metastasis by neutralizing adhesiveness and growth factors of sinusoidal endothelium. Cancer Res (2003) 63(2):491-7.

40. ten Hove T, van Montfrans C, Peppelenbosch MP, van Deventer SJ. Infliximab treatment induces apoptosis of lamina propria $\mathrm{T}$ lymphocytes in Crohn's disease. Gut (2002) 50(2):206-11. doi:10.1136/ gut.50.2.206

41. Sandborn WJ, Feagan BG, Fedorak RN, Scherl E, Fleisher MR, Katz S, et al. A randomized trial of Ustekinumab, a human interleukin12/23 monoclonal antibody, in patients with moderate-to-severe Crohn's disease. Gastroenterology (2008) 135(4):1130-41. doi:10. 1053/j.gastro.2008.07.014

42. Mannon PJ, Fuss IJ, Mayer L, Elson CO, Sandborn WJ, Present D, et al. Anti-interleukin-12 antibody for active Crohn's disease. $N$ Engl J Med (2004) 351(20):2069-79. doi: 10.1056/NEJMoa033402

43. Pizarro TT, Michie MH, Bentz M, Woraratanadharm J, Smith MF Jr, Foley E, et al. IL-18, a novel immunoregulatory cytokine, is up-regulated in Crohn's disease: expression and localization in intestinal mucosal cells. J Immunol (1999) 162(11):6829-35.

44. Monteleone G, Trapasso F, Parrello T, Biancone L, Stella A, Iuliano R, et al. Bioactive IL-18 expression is up-regulated in Crohn's disease. J Immunol (1999) 163(1):143-7.

45. Ten Hove T, Corbaz A, Amitai H, Aloni S, Belzer I, Graber P, et al. Blockade of endogenous IL18 ameliorates TNBS-induced colitis by decreasing local TNF-alpha production in mice. Gastroenterology (2001) 121(6):1372-9. doi:10. 1053/gast.2001.29579

46. Siegmund B. Interleukin-1b converting enzyme and intestinal inflammation. Biochem Pharmacol (2002) 7273:1-8. doi:10.1016/ S0006-2952(02)01064-X

47. Bauer C, Duewell P, Mayer C, Lehr HA, Fitzgerald KA, Dauer M, et al. Colitis induced in mice with dextran sulfate sodium (DSS) is mediated by the NLRP3 inflammasome. Gut (2010) 59(9):1192-9. doi:10.1136/gut.2009.197822

48. Bauer C, Loher F, Dauer M, Mayer C, Lehr HA, Schonharting $\mathrm{M}$, et al. The ICE inhibitor pralnacasan prevents DSS-induced colitis in C57BL/6 mice and suppresses IP-10 mRNA but not TNFalpha mRNA expression. Dig Dis Sci (2007) 52(7):1642-52. doi:10. 1007/s10620-007-9802-8

49. Loher F, Bauer C, Landauer N, Schmall K, Siegmund B, Lehr $\mathrm{HA}$, et al. The interleukin-1 betaconverting enzyme inhibitor pralnacasan reduces dextran sulfate sodium-induced murine colitis and $\mathrm{T}$ helper 1 T-cell activation. J Pharmacol Exp Ther (2004) 308(2):583-90. doi:10.1124/jpet. 103.057059

50. Banerjee S, Bond JS. Prointerleukin-18 is activated by meprin beta in vitro and in vivo in intestinal inflammation. $J$ Biol Chem (2008) 283(46):31371-7. doi:10.1074/jbc.M802814200

51. Allen IC, TeKippe EM, Woodford RM, Uronis JM, Holl EK, Rogers $\mathrm{AB}$, et al. The NLRP3 inflammasome functions as a negative regulator of tumorigenesis during colitis-associated cancer. J Exp Med (2010) 207(5):1045-56. doi: 10.1084/jem.20100050

52. Dupaul-Chicoine J, Yeretssian G, Doiron K, Bergstrom KS, McIntire CR, LeBlanc PM, et al. Control of intestinal homeostasis, colitis, and colitis-associated colorectal cancer by the inflammatory caspases. Immunity (2010) 32(3):367-78. doi:10.1016/j.immuni.2010.02. 012

53. Hirota SA, Ng J, Lueng A, Khajah M, Parhar K, Li Y, et al. NLRP3 inflammasome plays a key role in the regulation of intestinal homeostasis. Inflamm Bowel Dis (2011) 17(6):1359-72. doi:10. 1002/ibd.21478

54. Elinav E, Strowig T, Kau AL, Henao-Mejia J, Thaiss CA, Booth CJ, et al. NLRP6 inflammasome regulates colonic microbial ecology and risk for colitis. Cell (2011) 145(5):745-57. doi:10.1016/j.cell. 2011.04.022

55. Chen CJ, Kono H, Golenbock D, Reed G, Akira S, Rock KL. Identification of a key pathway required for the sterile inflammatory response triggered by dying cells. Nat Med (2007) 13(7):851-6. doi:10.1038/nm1603

56. Siegmund B. Interleukin-18 in intestinal inflammation: friend and foe? Immunity (2010) 32(3):300-2. doi:10.1016/j. immuni.2010.03.010

57. Netea MG, Joosten LA, Lewis E, Jensen DR, Voshol PJ, Kullberg BJ, et al. Deficiency of interleukin-18 
in mice leads to hyperphagia, obesity and insulin resistance. Nat Med (2006) 12(6):650-6. doi:10.1038/ nm1415

58. Zorrilla EP, Sanchez-Alavez M, Sugama S, Brennan M, Fernandez R, Bartfai T, et al. Interleukin18 controls energy homeostasis by suppressing appetite and feed efficiency. Proc Natl Acad Sci U S A (2007) 104(26):11097-102. doi:10. 1073/pnas.0611523104

59. Abbate A, Van Tassell BW, Seropian IM, Toldo S, Robati R, Varma A, et al. Interleukin-1beta modulation using a genetically engineered antibody prevents adverse cardiac remodelling following acute myocardial infarction in the mouse. Eur J Heart Fail (2010) 12(4):319-22. doi:10.1093/eurjhf/hfq017

60. Abbate A, Salloum FN, Vecile E, Das A, Hoke NN, Straino S, et al. Anakinra, a recombinant human interleukin-1 receptor antagonist, inhibits apoptosis in experimental acute myocardial infarction. Circulation (2008) 117(20):2670-83. doi:10.1161/ CIRCULATIONAHA.107.740233

61. Abbate A, Kontos MC, Grizzard JD, Biondi-Zoccai GG, Van Tassell BW, Robati R, et al. Interleukin-1 blockade with anakinra to prevent adverse cardiac remodeling after acute myocardial infarction (Virginia Commonwealth University Anakinra Remodeling Trial [VCUART] Pilot study). Am J Cardiol (2010) 105(10):1371-77.e1. doi: 10.1016/j.amjcard.2009.12.059

62. Abbate A, Van Tassell BW, BiondiZoccai G, Kontos MC, Grizzard JD, Spillman DW, et al. Effects of interleukin-1 blockade with anakinra on adverse cardiac remodeling and heart failure after acute myocardial infarction [from the Virginia Commonwealth University-Anakinra Remodeling Trial (2) (VCU-ART2) pilot study]. Am J Cardiol (2013) 111(10):1394-400. doi:10.1016/j. amjcard.2013.01.287

63. Van Tassell BW, Arena R, Toldo S, Mezzaroma E, Azam T, Seropian IM, et al. Enhanced interleukin1 activity contributes to exercise intolerance in patients with systolic heart failure. PLoS One (2012) 7(3):e33438. doi:10.1371/journal. pone. 0033438

64. Ridker PM, Thuren T, Zalewski A, Libby P. Interleukin-1beta inhibition and the prevention of recurrent cardiovascular events: rationale and design of the Canakinumab Antiinflammatory Thrombosis Outcomes Study (CANTOS). Am Heart J (2011) 162(4):597-605. doi:10.1016/j.ahj.2011.06.012

65. Mallat Z, Heymes C, Corbaz A, Logeart D, Alouani S, CohenSolal A, et al. Evidence for altered interleukin 18 (IL)-18 pathway in human heart failure. FASEB $J$ (2004) 18(14):1752-4.

66. Platis A, Yu Q, Moore D, Khojeini E, Tsau P, Larson D. The effect of daily administration of IL-18 on cardiac structure and function. Perfusion (2008) 23(4):237-42.

67. Woldbaek PR, Sande JB, Stromme TA, Lunde PK, Djurovic S, Lyberg T, et al. Daily administration of interleukin-18 causes myocardial dysfunction in healthy mice. Am J Physiol Heart Circ Physiol (2005) 289(2):H708-14. doi:10.1152/ ajpheart.01179.2004

68. Raeburn CD, Dinarello CA, Zimmerman MA, Calkins CM, Pomerantz BJ, McIntyre RC Jr, et al. Neutralization of IL-18 attenuates lipopolysaccharide-induced myocardial dysfunction. Am Physiol (2002) 283(2):H650-7.

69. Pomerantz BJ, Reznikov LL, Harken AH, Dinarello CA. Inhibition of caspase 1 reduces human myocardial ischemic dysfunction via inhibition of IL-18 and IL-1beta. Proc Natl Acad Sci U S A (2001) 98(5):2871-6. doi:10.1073/pnas.041611398

70. Doyle SL, Campbell M, Ozaki E, Salomon RG, Mori A, Kenna PF, et al. NLRP3 has a protective role in age-related macular degeneration through the induction of IL-18 by drusen components. Nat Med (2012) 18:791-8. doi:10.1038/nm. 2717

71. Novick D, Kim SH, Fantuzzi G, Reznikov L, Dinarello CA, Rubinstein $\mathrm{M}$. Interleukin-18 binding protein: a novel modulator of the Thl cytokine response. Immunity (1999) 10:127-36. doi:10. 1016/S1074-7613(00)80013-8

72. Kim SH, Eisenstein M, Reznikov L, Fantuzzi G, Novick D, Rubinstein $\mathrm{M}$, et al. Structural requirements of six naturally occurring isoforms of the IL-18 binding protein to inhibit IL-18. Proc Natl Acad Sci U S A (2000) 97:1190-5.

73. Novick D, Schwartsburd B, Pinkus R, Suissa D, Belzer I, Sthoeger Z, et al. A novel IL18BP ELISA shows elevated serum il-18BP in sepsis and extensive decrease of free IL-18.
Cytokine (2001) 14(6):334-42. doi:10.1006/cyto.2001.0914

74. Novick D, Elbirt D, Dinarello CA, Rubinstein M, Sthoeger ZM. Interleukin-18 binding protein in the sera of patients with Wegener's granulomatosis. J Clin Immunol (2009) 29(1):38-45. doi:10.1007/ s10875-008-9217-0

75. Novick D, Elbirt D, Miller G, Dinarello CA, Rubinstein $M$, Sthoeger ZM. High circulating levels of free interleukin-18 in patients with active SLE in the presence of elevated levels of interleukin-18 binding protein. $J$ Autoimmun (2011) 34(2):121-6. doi:10.1016/j.jaut.2009.08.002

76. Bufler P, Azam T, GamboniRobertson F, Reznikov LL, Kumar S, Dinarello CA, et al. A complex of the IL-1 homologue IL-1F7b and IL-18-binding protein reduces IL18 activity. Proc Natl Acad Sci U S A (2002) 99(21):13723-8. doi:10. 1073/pnas.212519099

77. Dinarello C, Arend W, Sims J, Smith D, Blumberg H, O'Neill L, et al. IL-1 family nomenclature. Nat Immunol (2010) 11(11):973. doi:10.1038/ni1110-973

78. McNamee EN, Masterson JC, Jedlicka P, McManus M, Grenz $\mathrm{A}$, Collins $\mathrm{CB}$, et al. Interleukin 37 expression protects mice from colitis. Proc Natl Acad Sci U S A (2011) 108(40):16711-6. doi:10. 1073/pnas.1111982108

79. Banda NK, Vondracek A, Kraus D, Dinarello CA, Kim SH, Bendele A, et al. Mechanisms of inhibition of collagen-induced arthritis by murine IL-18 binding protein. J Immunol (2003) 170(4):2100-5.

80. Muhl H, Kampfer H, Bosmann M, Frank S, Radeke H, Pfeilschifter J. Interferon-gamma mediates gene expression of IL-18 binding protein in nonleukocytic cells. Biochem Biophys Res Commun (2000) 267(3):960-3. doi:10.1006/bbrc.1999.2064

81. Hurgin V, Novick D, Rubinstein M. The promoter of IL18 binding protein: activation by an IFN-gamma-induced complex of IFN regulatory factor 1 and CCAAT/enhancer binding protein beta. Proc Natl Acad Sci U S A (2002) 99(26):16957-62. doi:10. 1073/pnas.262663399

82. Kaser A, Novick D, Rubinstein M, Siegmund B, Enrich B, Koch RO, et al. Interferon-alpha induces interleukin-18 binding protein in chronic hepatitis C patients. Clin Exp Immunol (2002)
129(2):332-8. doi:10.1046/j.13652249.2002.01911.x

83. Ludwiczek O, Kaser A, Novick D, Dinarello CA, Rubinstein M, Vogel W, et al. Plasma levels of interleukin-18 and interleukin18 binding protein are elevated in patients with chronic liver disease. J Clin Immunol (2002) 22(6):331-7. doi:10.1023/ A:1020600230977

84. Wittmann M, Bachmann M, Doble R, Pfeilschifter J, Werfel T, Mühl H. IL-27 regulates IL-18 binding protein in skin resident cells. PLoS One (2012) 7(6):e38751. doi:10.1371/ journal.pone.0038751

85. Xiang Y, Moss B. Correspondence of the functional epitopes of poxvirus and human interleukin18-binding proteins. J Virol (2001) 75(20):9947-54. doi:10.1128/JVI. 75.20.9947-9954.2001

86. Grom AA. Macrophage activation syndrome and reactive hemophagocytic lymphohistiocytosis: the same entities? Curr Opin Rheumatol (2003) 15(5):587-90. doi:10.1097/ 00002281-200309000-00011

87. Grom AA, Mellins ED. Macrophage activation syndrome: advances towards understanding pathogenesis. Curr Opin Rheumatol (2011) 22(5):561-6. doi:10. 1097/01.bor.0000381996.69261.71

88. Grom AA, Villanueva J, Lee S, Goldmuntz EA, Passo MH, Filipovich A. Natural killer cell dysfunction in patients with systemic-onset juvenile rheumatoid arthritis and macrophage activation syndrome. $J$ Pediatr (2003) 142(3):292-6. doi:10.1067/mpd.2003.110

89. Janka GE. Familial and acquired hemophagocytic lymphohistiocytosis. Annu Rev Med (2012) 63:233-46. doi:10.1146/annurevmed-041610-134208

90. Ogilvie EM, Khan A, Hubank M, Kellam P, Woo P. Specific gene expression profiles in systemic juvenile idiopathic arthritis. Arthritis Rheum (2007) 56(6):1954-65. doi:10.1002/art.22644

91. Sumegi J, Barnes MG, Nestheide SV, Molleran-Lee S, Villanueva J, Zhang K, et al. Gene expression profiling of peripheral blood mononuclear cells from children with active hemophagocytic lymphohistiocytosis. Blood (2011) 117(15):e151-60. doi:10. 1182/blood-2010-08-300046

92. Maeno N, Takei S, Imanaka H, Yamamoto K, Kuriwaki K, Kawano 
$\mathrm{Y}$, et al. Increased interleukin-18 expression in bone marrow of a patient with systemic juvenile idiopathic arthritis and unrecognized macrophageactivation syndrome. Arthritis Rheum (2004) 50(6):1935-8. doi:10.1002/art.20268

93. Emmenegger U, Reimers A, Frey U, Fux C, Bihl F, Semela D, et al. Reactive macrophage activation syndrome: a simple screening strategy and its potential in early treatment initiation. Swiss Med Wkly (2002) 132(17-18):230-6.

94. Nold-Petry CA, Lehrnbecher T, Jarisch A, Schwabe D, Pfeilschifter JM, Muhl $\mathrm{H}$, et al. Failure of interferon gamma to induce the anti-inflammatory interleukin 18 binding protein in familial hemophagocytosis. PLoS One (2010) 5(1):e8663. doi:10.1371/ journal.pone.0008663

95. Honda K, Ohga S, Takada H, Nomura A, Ohshima K, Kinukawa $\mathrm{N}$, et al. Neuron-specific enolase in hemophagocytic lymphohistiocytosis: a potential indicator for macrophage activation? Int $J$ Hematol (2000) 72(1):55-60.

96. Wada T, Muraoka M, Yokoyama $\mathrm{T}$, Toma $\mathrm{T}$, Kanegane $\mathrm{H}$, Yachie A. Cytokine profiles in children with primary Epstein-Barr virus infection. Pediatr Blood Cancer (2013) 60(7):E46-8. doi:10.1002/ pbc. 24480

97. Fitzgerald AA, Leclercq SA, Yan A, Homik JE, Dinarello CA. Rapid responses to anakinra in patients with refractory adult-onset Still's disease. Arthritis Rheum (2005) 52(6):1794-803. doi:10.1002/art. 21061

98. Larroche C, Mouthon L. Pathogenesis of hemophagocytic syndrome (HPS). Autoimmunity Rev (2004) 3:69-75. doi:10.1016/ S1568-9972(03)00091-0

99. Favilli F, Anzilotti C, Martinelli L, Quattroni P, De Martino S, Pratesi F, et al. IL-18 activity in systemic lupus erythematosus. Ann N
Y Acad Sci (2009) 1173:301-9. doi:10.1111/j.1749-6632.2009. 04742.x

100. Emmanuilidis $\mathrm{K}$, Weighardt $\mathrm{H}$, Matevossian E, Heidecke CD, Ulm $\mathrm{K}$, Bartels $\mathrm{H}$, et al. Differential regulation of systemic IL-18 and IL-12 release during postoperative sepsis: high serum IL-18 as an early predictive indicator of lethal outcome. Shock (2002) 18(4):301-5. doi:10.1097/ 00024382-200210000-00002

101. Mommsen P, Frink M, Pape HC, van Griensven M, Probst C, Gaulke R, et al. Elevated systemic IL-18 and neopterin levels are associated with posttraumatic complications among patients with multiple injuries: a prospective cohort study. Injury (2009) 40(5):528-34. doi:10.1016/j.injury.2008.08.007

102. Palladino I, Salani F, Ciaramella A, Rubino IA, Caltagirone C, Fagioli $\mathrm{S}$, et al. Elevated levels of circulating IL-18BP and perturbed regulation of IL-18 in schizophrenia. J Neuroinflammation (2012) 9:206. doi:10.1186/1742-2094-9-206

103. Haas SL, Abbatista M, Brade J, Singer MV, Bocker U. Interleukin18 serum levels in inflammatory bowel diseases: correlation with disease activity and inflammatory markers. Swiss Med Wkly (2009) 139(9-10):140-5.

104. Ludwiczek O, Kaser A, Novick D, Dinarello CA, Rubinstein M, Tilg H. Elevated systemic levels of free interleukin-18 (IL-18) in patients with Crohn's disease. Eur Cytokine Netw (2005) 16(1): 27-33.

105. Bokarewa M, Hultgren O. Is interleukin-18 useful for monitoring rheumatoid arthritis? Scand J Rheumatol (2005) 34(6):433-6. doi:10.1080/ 03009740510026724

106. Jelusic M, Lukic IK, TambicBukovac L, Dubravcic K, Malcic I, Rudan I, et al. Interleukin-18 as a mediator of systemic juvenile idiopathic arthritis. Clin Rheumatol (2007) 26(8):1332-4. doi:10. 1007/s10067-006-0474-0

107. Kawashima M, Yamamura M, Taniai M, Yamauchi H, Tanimoto T, Kurimoto $M$, et al. Levels of interleukin-18 and its binding inhibitors in the blood circulation of patients with adult-onset Still's disease. Arthritis Rheum (2001) 44(3):550-60. doi:10.1002/15290131(200103)44:3<550::AIDANR103>3.0.CO;2-5

108. Blankenberg S, Luc G, Ducimetiere P, Arveiler D, Ferrieres J, Amouyel $\mathrm{P}$, et al. Interleukin-18 and the risk of coronary heart disease in European men: the Prospective Epidemiological Study of Myocardial Infarction (PRIME). Circulation (2003) 108(20):2453-9. doi:10.1161/01.CIR.0000099509. 76044.A2

109. Narins CR, Lin DA, Burton PB, Jin ZG, Berk BC. Interleukin-18 and interleukin-18 binding protein levels before and after percutaneous coronary intervention in patients with and without recent myocardial infarction. Am J Cardiol (2004) 94(10):1285-7. doi:10. 1016/j.amjcard.2004.07.114

110. Thompson SR, Novick D, Stock CJ, Sanders J, Brull D, Cooper $\mathrm{J}$, et al. Free Interleukin (IL)18 levels, and the impact of IL18 and IL18BP genetic variation, in CHD patients and healthy men. Arterioscler Thromb Vasc Biol (2007) 27(12):2743-9. doi:10. 1161/ATVBAHA.107.149245

111. Troseid M, Seljeflot I, Arnesen H. The role of interleukin-18 in the metabolic syndrome. Cardiovasc Diabetol (2010) 9:11. doi:10.1186/ 1475-2840-9-11

112. Parikh CR, Abraham E, Ancukiewicz M, Edelstein CL. Urine IL-18 is an early diagnostic marker for acute kidney injury and predicts mortality in the ICU. $J A m$ Soc Nephrol (2005) 16(10):3046-52. doi:10.1681/ASN.2005030236
113. Vaidya VS, Waikar SS, Ferguson MA, Collings FB, Sunderland $\mathrm{K}$, Gioules $\mathrm{C}$, et al. Urinary biomarkers for sensitive and specific detection of acute kidney injury in humans. Clin Transl Sci (2008) 1(3):200-8. doi:10. 1111/j.1752-8062.2008.00053.x

114. Parikh CR, Mishra J, ThiessenPhilbrook H, Dursun B, Ma Q, Kelly C, et al. Urinary IL-18 is an early predictive biomarker of acute kidney injury after cardiac surgery. Kidney Int (2006) 70(1):199-203. doi:10.1038/sj.ki.5001527

115. Sirota JC, Walcher A, Faubel S, Jani A, McFann K, Devarajan P, et al. Urine IL-18, NGAL, IL-8 and serum IL- 8 are biomarkers of acute kidney injury following liver transplantation. BMC Nephrol (2013) 14:17. doi:10.1186/1471-2369-14-17

Conflict of Interest Statement: The authors declare that the research was conducted in the absence of any commercial or financial relationships that could be construed as a potential conflict of interest.

Received: 31 May 2013; accepted: 04 September 2013; published online: 08 October 2013.

Citation: Dinarello CA, Novick D, Kim S and Kaplanski G (2013) Interleukin-18 and $I L-18$ binding protein. Front. Immunol. 4:289. doi: 10.3389/fimmu.2013.00289

This article was submitted to Inflammation, a section of the journal Frontiers in Immunology.

Copyright (c) 2013 Dinarello, Novick, Kim and Kaplanski. This is an openaccess article distributed under the terms of the Creative Commons Attribution License (CC BY). The use, distribution or reproduction in other forums is permitted, provided the original author(s) or licensor are credited and that the original publication in this journal is cited, in accordance with accepted academic practice. No use, distribution or reproduction is permitted which does not comply with these terms. 